\title{
MODEL OF PRODUCTION CONTROL IN JUST-IN-TIME DELIVERY SYSTEM CONDITONS
}

\author{
Edward Kozłowski, Arkadiusz Gola, Antoni Świć
}

\begin{abstract}
S u m mary
The article presents the mathematical model of production control in the Just-in-time delivery system's conditions for a planning fixed horizon. The aim of the control model is to determine the demand for means of production (materials, labour force) at the right moment of time. The stochastic model of appearing the fault products was taking into account. Minimization both the costs of manufacturing and possible penalties connected with the incomplete execution of the order was taken as a criterion of optimization process.
\end{abstract}

Keywords: production control, Just-in-Time, strategy, optimization, planning fixed horizon

Model sterowania produkcją w warunkach dostaw w systemie Just-in-Time

Streszczenie

W pracy przedstawiono matematyczny model sterowania produkcją $\mathrm{w}$ warunkach dostaw w systemie Just-in-time, w określonym horyzoncie czasowym. Model sterujący określa zapotrzebowanie na środki produkcji (materiały, siła robocza) w zdefiniowanych momentach czasu. Pod uwagę wzięto stochastyczny model występowania wyrobów wadliwych w procesie produkcyjnym. Jako kryterium optymalizacji rozważano minimalizację kosztów produkcji oraz ewentualnych kar związanych z niepełną realizacją zamówień.

Słowa kluczowe: sterowanie produkcją, strategia, Just-in-Time, optymalizacja, określony horyzont planowania

\section{Introduction}

Nowadays, one of the most important factors of manufacturing company's competitiveness is ability to realize the customer's orders in time and quantity exactly according to the contract [1]. Manufacturing plants must satisfy the customer demand neither late nor early, because early production incurs inventory holding cost and late production causes either lost sales or backlog. Therefore, parts supply to the point of use in the assembly line must be also

Address: Edward KOZŁOWSKI, PhD Eng., Lublin University of Technology, Department of Quantitative Methods in Management, Arkadiusz GOLA, PhD Eng., Lublin University of Technology, Department of Enterprise Organization, Prof. Antoni ŚWIĆ, PhD Eng., Lublin University of Technology, Institute of Technological Systems of Information, 20-618 Lublin, ul. Nadbystrzycka 38, phone: + 488153844 83, fax: +48 8153846 81, e-mail: a.gola@pollub.pl 
achieved Just-in-Time (JIT). Otherwise, either time losses may occur due to disorganized and insufficient material supply to the assembly line, or excess inventory accumulates [2-4].

This JIT products delivery to the customers imposes specific requirements to the process of production control. Manufacturing planning and control entails the acquisition and allocation of limited resources to production activities so as to satisfy customer demand over a specified time horizon [5]. As such, planning and control problems are inherently optimization problems, where the objective is to develop a plan that meets demand at minimum cost or that fills the demand that maximizes profit.

During the last decade, various articles have appeared in professional and scientific journals regarding production control in process industries. The vast majority have focused on the typical characteristics of process industries production control vis-à-vis the more traditional approaches of production control for discrete manufacturing systems. In this body of literature, two schools of taught can be distinguished. The first advocates the applicability of traditional manufacturing requirements planning (MRP) concepts and systems in process industries. The researchers and practitioners in this school concentrate on the specific characteristics that may occur in process industries and try to find solutions to be able to implement MRP [6]. The second school stresses the differences between discrete and process manufacturers and comes with new or adapted techniques and concepts for production control in these situations. Very seldom is the variety of production systems within process industries discussed. Some articles do address the problem of variety (or the opportunity and offers), but consequences for production control are not worked out in more detail [7].

Research on optimal control of production processes in made-to-order manufacture and assembly systems has been limited. Fransoo presents a typology of production control situations in process industries, which recognizes two extreme production systems on a continuum [7]. Chen et al. [8] obtained the optimal policy for a system where finished products is produced as soon as there are units in inventory for all components. Benjaafar and ElHafsi [9] characterized the optimal policy of a single product multiple customer class multiple customer class system. Subsequently Benjaafar et al. [10] characterized the optimal policy of a single product multiple customer class multi-stage system. Also Millhiser et al. [11] dealt with the problem of dynamic control of arrivals of multiple job classes in $\mathrm{N}$-stage production systems with finite buffers and blocking after service. Gershwin [12] synthesized related work from the manufacturing flow control literature. Kushner [13] and Plambeck and Ward [14] formulated Brownian control problems and derived asymptotically optimal polices. Ceryan et al. [15] characterized the optimal policy for assemble system where demand may arise for the end product itself or any one of the components. More recently Liao [16] examined the feasibility of using an economic production quantity (EPQ) model to model an imperfect process involving 
a deteriorating production systems. Similarly, Sarkar and Sarkar [17] presented an economic manufacturing quantity model with deterioration and exponential demand inf production system over a finite horizon under the effect of inflation and time value of money. Finally, Ghelase et al. [18] proposed a method to control the entire production process, from customer enquiry up to product delivery, for the Made-to-Stock manufacturing systems.

In this article, we present a mathematical model of optimal production control for a fixed horizon where the produced failure parts are characterized by stochastic log-normal function. We will consider the manufacturing process realized in both Made-to-Order and Just-in-Time systems. The objective of the proposed model is the minimization of the total production costs and costs with failure to perform the order.

\section{Problem formulation}

Let us consider the problem of production control for a fixed horizon defined by the customer's order. The question is to determine the quantity of means of production at defined moment to realize the customer order with the minimum cost of production and possible fees connected with not-fulfillment the order conditions.

The objective function determines total costs, which are sum of production costs and costs associated with failure to perform the contract $a$, which can be realized at time $N$. Total cost is called a composite cost function (CCF). Let $(\Omega$, $F, P)$ be a complete probability space. Suppose that $w_{1}, w_{2}, \ldots$ are independent $n$ dimensional random wectors on this space $\left(w_{s}=\operatorname{col}\left(w_{1}(s), w_{2}(\mathrm{~s}), \ldots, w_{n}(s)\right)\right.$ for $s=1,2, \ldots)$, where all elements of $w_{i}(s)$ have log-normal $L N\left(m_{i}, \sigma_{i}\right)$ distribution and are stochastically independent $\left(\mathrm{w}_{\mathrm{i}}(\mathrm{s}) \perp w_{j}(t)\right.$ for $i \neq j$ or $\left.s \neq t\right)$.

Let the stste system be described by a state equation:

$$
x_{i+1}=x_{i}+B u_{i}-w_{i+1}
$$

where: $i=0, \ldots, N-1, x_{i} \in R^{n}, B \in R^{n x k}$. The matrix $B$ represents a production matrix (transformation matrix from resources to products).

Remark. Let $x$ - production vector and the matrix $C$ is a matrix of raw material at the production unit (matrix of resources consumption), then the vector of used resources to product is calculated as:

$$
u=C x
$$

while the production matrix 


$$
B=\left(C^{T} C\right)^{-1} C^{T}
$$

and

$$
x=B u
$$

On $(\Omega, F, P)$ we define a family of sub- $\sigma$-fields $\mathrm{Y}_{\mathrm{j}}=\sigma\left\{\mathrm{y}_{\mathrm{i}}: i=0,1, \ldots, j\right\}$. A $\mathrm{Y}_{\mathrm{j}}$-measurable vector $u_{j} \in R^{k}$ will be called a control action of system (1) and presents a production, and $u=\left(u_{0}, u_{1}, \ldots\right)$ an admissible control. The class of admissible controls is denoted by $U$. Let the vector $K \in R^{k}$ is a vector of unit costs during the production but the matrix $Q \in R^{n x k}$ is a matrix of coefficients of quadratic costs. To specify the aim of control, we introduce a cost of production at time $i$ as $u_{i}^{T} Q u_{i}+K^{T} u_{i}$ and a heredity function $\alpha\left\|x_{N}-a\right\|^{2}$ as losses (add costs) associated with failure to perform the contrach. The objective function has a form

$$
J(u)=E\left[\sum_{i=0}^{N-1}\left(u_{i}^{T} Q u_{i}+K^{T} u_{i}\right)+\alpha\left\|x_{N}-a\right\|^{2}\right]
$$

The main aim of optimal control is stabilization of system (1) at lowest cost, which is a sum of costs and losses. Then, the task is to find

$$
\inf _{u \in U} J(u)
$$

and to determine a sequence of admissible control $u^{*}=\left(u_{0}^{*}, \ldots, u_{r-1}^{*}\right)$ for which the infimum is attained. In this case the time horizon $N$ is defined. Some examples of tasks with random time horizon are presented in [19] and [20].

Remark 1. For each $t \geq 1$ the vector of expected values of disturbances $w_{t} i s$ :

$$
m=E w_{t}=\left(\begin{array}{c}
E w_{1}(t) \\
E w_{2}(t) \\
\cdots \\
E w_{n}(t)
\end{array}\right)=\left(\begin{array}{c}
e^{m_{1}+\frac{\sigma_{1}^{2}}{2}} \\
e^{m_{2}+\frac{\sigma_{2}^{2}}{2}} \\
\cdots \\
e^{m_{n}+\frac{\sigma_{n}^{2}}{2}}
\end{array}\right)
$$


Remark 2. For any $t \neq s$ the covariance matrix of vectors $w_{t}$ and $w_{s}$ is a zero matrix because all elements of this vector (random variables) are independent:

$$
\operatorname{cov}\left(w_{t}, w_{s}\right)=[0]
$$

Remark 3. The covariance matrix of vector $w_{t}$ for $t \geq 1$ is:

$$
\Sigma=\operatorname{cov}\left(w_{t}, w_{t}\right)=E\left(w_{t}-E w_{t}\right)\left(w_{t}-E w_{t}\right)^{T}=\left(\begin{array}{cccc}
z_{1} & 0 & \ldots & 0 \\
0 & z_{2} & \ldots & 0 \\
. & . & \ldots & . \\
0 & 0 & \ldots & z_{n}
\end{array}\right)
$$

where $z_{i}=e^{2 m_{i}+\sigma_{i}^{2}}\left(e^{\sigma_{i}^{2}}-1\right)$ for $0 \leq i \leq n$.

\section{Optimal control}

Let the linear system be described by a state equation (1) and the criterion with deterministic horizon $N$ is:

$$
\inf _{u \in U} E\left[\sum_{i=0}^{N-1}\left(u_{i}^{T} Q u_{i}+K^{T} u_{i}\right)+\alpha\left\|x_{N}-a\right\|^{2}\right]
$$

The theorem below presents an optimal control of system (1) and value of composite costs function.

Theorem 1. Let

$$
\begin{gathered}
M_{i}=M_{i+1}-M_{i+1}^{T} B H_{i+1}^{T} M_{i+1} \\
L_{i}=L_{i+1}-2 M_{i+1} m-M_{i+1}^{T} B H_{i+1}^{-1}\left(B^{T}\left(L_{i+1}-2 M_{i+1} m\right)+K\right) \\
Z_{i}=-\frac{1}{4} K^{T} H_{i+1}^{-1} K+K^{T} H_{i+1}^{-1} B^{T}\left(M_{i=1} m-\frac{1}{2} L_{i+1}\right)-\frac{1}{4} L_{i+1}^{T} B H_{i+1}^{-1} B^{T} L_{i+1} \\
+m^{T} M_{i+1}^{T} B H_{i+1}^{-1} B^{T}\left(L_{i+1}-M_{i+1} m\right)+m^{T} M_{i+1} m-m^{T} L_{i+1}+Z_{i+1}+\operatorname{tr}\left(M_{i+1} \Sigma\right)
\end{gathered}
$$


where $H_{i+1}=Q+B^{T} M_{i+1} B$ for $i=0,1, \ldots, \mathrm{N}-1$ and $M_{N}=\alpha I, L_{N}=-2 \alpha a, Z_{N}$ $=\alpha a^{T} a$.

If $\operatorname{det}\left(\mathrm{H}_{\mathrm{i}+1}\right) \neq 0$, then the optimal control is:

$$
u_{i}^{*}=-\frac{1}{2} H_{i+1}^{-1}\left(K+2 B^{T} M_{i+1}\left(x_{i}-m\right)+B^{T} L_{i+1}\right)
$$

and

$$
E\left[\sum_{i=0}^{N-1}\left(u_{i}^{T} Q u_{i}+K^{T} u_{i}\right)+\alpha\left\|x_{N}-a\right\|^{2}\right]=W_{0}\left(x_{0}\right)
$$

where

$$
W_{i}\left(x_{i}\right)=x_{i}^{T} M_{i} x_{i}+x_{i}^{T} L_{i}+Z_{i}
$$

Proof. First we define the Bellman's [21, 22] functions which are non-negative (they are defined as a sum of quadratic forms). For the time $\mathrm{N}$ we have:

$$
W_{N}\left(x_{N}\right)=\alpha\left\|x_{N}-a\right\|^{2}=x_{N}^{T} M_{N} x_{N}+x_{N}^{T} L_{N}+Z_{N}
$$

and

$$
W_{i}\left(x_{i}\right)=\min _{u_{i}} E\left\{u_{i}^{T} Q u_{i}+K^{T} u_{i}+W_{i+1}\left(x_{i+1}\right) \mid F_{i}\right\}
$$

for $j=0,1, \ldots, N-1$. The varule of Bellman's function in step $N$ is given by (17) and in step $N-1$ we have:

$$
\begin{gathered}
\begin{aligned}
W_{N-1}\left(x_{N-1}\right)= & \min _{u_{N-1}} E\left\{u_{N-1}^{T} Q u_{N-1}+K^{T} u_{N-1}+W_{N}\left(x_{N}\right) \mid F_{N-1}\right\} \\
& =\min _{u_{N-1}}\left\{u_{N-1}^{T}\left(Q+B^{T} M_{N} B\right) u_{N-1}\right.
\end{aligned} \\
+u_{N-1}^{T}\left(K+2 B^{T} M_{N}\left(x_{N-1}-E\left(w_{N} \mid F_{N-1}\right)\right)+B^{T} L_{N}\right) \\
+x_{N-1}^{T} M_{N} x_{N-1}+E\left(w_{N}^{T} M_{N} w_{N} \mid F_{N-1}\right)-2 x_{N-1}^{T} M_{N} E\left(w_{N} \mid F_{N-1}\right) \\
\left.-2 x_{N-1}^{T} M_{N} E\left(w_{N} \mid F_{N-1}\right)=x_{N-1}^{T} L_{N}-E\left(w_{N}^{T} \mid F_{N-1}\right) L_{N}+Z_{N}\right\}
\end{gathered}
$$


From the stochastically independent of vectors $w_{1}, w_{2}, \ldots$, properties of condition expectation and (7)-(9) we have:

$$
\begin{gathered}
E\left(w_{N} \mid F_{N-1}\right)=m \\
E\left(w_{N}^{T} M_{N} w_{n} \mid F_{N-1}\right)=\operatorname{tr} E\left(M_{N} W_{N} w_{N}^{T} \mid F_{N-1}\right)=\operatorname{tr}\left(M_{N}\left(\Sigma+m m^{T}\right)\right) \\
=\operatorname{tr}\left(M_{N} \Sigma\right)+m^{T} M_{N} m
\end{gathered}
$$

Thus, the optimal control is:

$$
u_{N-1}^{*}=-\frac{1}{2}\left(Q+B^{T} M_{N} B\right)^{-1}\left(K+2 B^{T} M_{N}\left(x_{n-1}-m\right)+B^{T} L_{N}\right)
$$

Then we have:

$$
\begin{gathered}
W_{N-1}\left(x_{N-1}\right)= \\
-\frac{1}{4}\left(K+2 B^{T} M_{N}\left(x_{N-1}-m\right)+B^{T} L_{N}\right)^{T} \\
*\left(Q+B^{T} M_{N} B\right)^{-1}\left(K+2 B^{T} M_{N}\left(x_{N-1}-m\right)+B^{T} L_{N}\right) \\
+x_{N-1}^{T} M_{N} x_{N-1}+\operatorname{tr}\left(M_{N} \Sigma\right)+m^{T} M_{N} m-2 x_{N-1}^{T} M_{N} m+x_{N-1}^{T} L_{N}+Z_{N} \\
=x_{N-1}^{T}\left(M_{N}-M_{N}^{T} B\left(Q+B^{T} M_{N} B\right)^{-1} B^{T} M_{N}\right) x_{N-1} \\
+x_{N-1}^{T}\left(L_{N}-2 M_{N} m+M_{N}^{T} B\left(Q+B^{T} M_{N} B\right)^{-1}\left(B^{T}\left(2 M_{N} m-L_{N}\right)-K\right)\right) \\
+K^{T}\left(Q+B^{T} M_{N} B\right)^{-1}\left(B^{T}\left(M_{N} m-\frac{1}{2} L_{N}\right)-\frac{1}{4} K\right) \\
+m^{T} M_{N}^{T} B\left(Q+B^{T} M_{N} B\right)^{-1} B^{T}\left(L_{N}-M_{N} m\right)-\frac{1}{4} L_{N}^{T} B\left(Q+B^{T} M_{N} B\right)^{-1} B^{T} L_{N} \\
+m^{T} M_{N} m-m^{T} L_{N}+Z_{N}+\operatorname{tr}\left(M_{N} \Sigma\right)=x_{N-1}^{T} M_{N-1} x_{N-1}+x_{N-1}^{T} L_{N-1}+Z_{N-1}
\end{gathered}
$$

We assume that equations (11)-(13) and (16) are true for $i+1$. From (18) and using the properties of condition expectation we have:

$$
\begin{gathered}
W_{i}\left(x_{i}\right)=\min _{u_{i}} E\left\{K^{T} u_{i}+W_{i+1}\left(x_{i+1}\right) \mid F_{i}\right\} \\
=\min _{u_{i}}\left\{u_{i}^{T}\left(Q+B^{T} M_{i+1} B\right) u_{i}+u_{i}^{T}\left(K+2 B^{T} M_{i+1}\left(x_{i}-m\right)+B^{T} L_{i+1}\right)\right. \\
\left.+x_{i}^{T} M_{i+1} x_{i}+E\left(w_{i+1}^{T} M_{i+1} w_{i+1} \mid F_{i}\right)-2 x_{i}^{T} M_{i+1} m+x_{i}^{T} L_{i+1}-m^{T} L_{i+1}+Z_{1+1}\right\}
\end{gathered}
$$

Thus, the optimal control is: 


$$
u_{i}^{*}=-\frac{1}{2}\left(Q+B^{T} M_{i+1} B\right)^{-1}\left(K+2 B^{T} M_{i+1}\left(x_{i}-m\right)+B^{T} L_{i+1}\right)
$$

and from (9):

$$
E\left(w_{i+1}^{T} M_{i+1} w_{i+1} \mid F_{i}\right)=\operatorname{tr}\left(M_{i+1} \Sigma\right)+m^{T} M_{i+1} m
$$

Finally, we have:

$$
\begin{gathered}
W_{i}\left(x_{i}\right)=x_{i}^{T}\left(M_{i+1}-M_{i+1}^{T} B\left(Q+B^{T} M_{i+1} B\right)^{-1} B^{T} M_{i+1}\right) x_{i} \\
+x_{i}^{T}\left(L_{i+1}-2 M_{i+1} m+M_{i+1}^{T} B\left(Q+B^{T} M_{i+1} B\right)^{-1}\left(B^{T}\left(2 M_{i+1} m-L_{i+1}\right)-K\right)\right) \\
+K^{T}\left(Q+B^{T} M_{i+1} B\right)^{-1}\left(B^{T}\left(M_{i+1} m-\frac{1}{2} L_{i+1}\right)-\frac{1}{4} K\right)+m^{T} M_{i+1} m-m^{T} L_{i+1} \\
+\operatorname{tr}\left(M_{i+1} \Sigma\right)+m^{T} M_{i+1}^{T} B\left(Q+B^{T} M_{i+1} B\right)^{-1} B^{T}\left(L_{i+1}-M_{i+1} m\right) \\
-\frac{1}{4} L_{i+1}^{T} B\left(Q+B^{T} M_{i+1} B\right)^{-1} B^{T} L_{i+1}+Z_{i+1}=x_{i}^{T} M_{i} x_{i}+x_{i}^{T} L_{i}+Z_{i}
\end{gathered}
$$

what finishes the proof.

\section{An illustrative example}

Let assume that the company produces two types of products: $\mathrm{x}_{1}$ and $\mathrm{x}_{2}$. To produce each of the product company uses two types means of production (for example material $(m)$, and labor force $(l)$ in quantities respectively: product $\mathrm{x}_{1}-$ 7,2 $m$ units and 1,9 $l$ units; product $\mathrm{x}_{1}-3,1 \mathrm{~m}$ units and 2,3 $l$ units. Unit cost of used material equals 0,5 and unit cost of labor force equals 1,1 . Therefore the matrix resources consumption $\mathrm{C}$ and vector of unit costs $\mathrm{K}$ are as follows:

$$
C=\left[\begin{array}{ll}
7,2 & 3,1 \\
1,9 & 2,3
\end{array}\right] \quad K=\left[\begin{array}{c}
0,5 \\
1,1
\end{array}\right]
$$

Ordered number of manufactured parts in at time $\mathrm{N}$ amounts 1500 units of product $\mathrm{x}_{1}$ and 400 units of product $\mathrm{x}_{2}$. Fixed horizon of production time was conventionally divided into five equal period of time defining the production control moments (Fig. 1). 


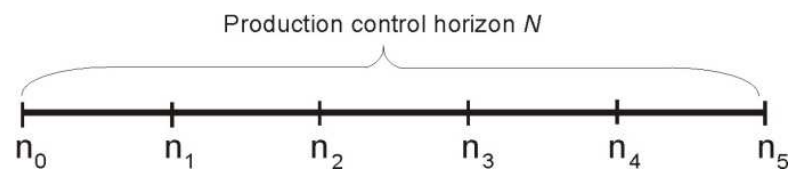

Fig. 1. Graphical interpretation of division of production control horizon

To check the behavior of the model three cases were analyzed. In first of them the unit cost associated with failure to perform the contract $(\alpha)$ was accepted at the level of 1 money unit while, in the second case the $\alpha=100$ and in the third case $\alpha=5000$. In each of the case the random parameters were defined as $\mathrm{m}_{1}=0.0000001 ; \mathrm{m}_{1}=0.00000003$ and $\sigma_{1}=1 ; \sigma_{2}=2$.

To check the model presented in part 3 , the experiment for presented data was carried out 50 times for each case. To illustrate obtained results - the average results of provided experiments were presented in Tab. 1-3.

Table 1. Obtained control results for $\alpha=1$

\begin{tabular}{|c|c|c|c|c|c|c|c|}
\hline \multirow{2}{*}{ Means of production category } & \multicolumn{7}{|c|}{ Production control moments } \\
\cline { 2 - 8 } & & $n_{0}$ & $n_{1}$ & $n_{2}$ & $n_{3}$ & $n_{4}$ & $n_{5}$ \\
\hline \multirow{2}{*}{$\begin{array}{c}\text { Number of produced good } \\
\text { quality products }\end{array}$} & $x_{1}$ & - & 77.38 & 157.10 & 236.7 & 315.0 & 396.2 \\
\cline { 2 - 8 } & $x_{2}$ & - & 297.8 & 594.74 & 893.4 & 1193.2 & 1492.6 \\
\hline $\begin{array}{c}\text { Demand for the means } \\
\text { of production for the next } \\
\text { period }\end{array}$ & $m$ & 750.0 & 751.5 & 752.82 & 754.0 & 758.2 & - \\
\cline { 2 - 8 } & $l$ & 2396.7 & 2399.2 & 2404.8 & 2408.7 & 2415.6 & - \\
\hline $\begin{array}{c}\text { Number of forecasted } \\
\text { faulty products }\end{array}$ & $x_{1}$ & 1.95 & 0.01 & 0.18 & 0.26 & 0.24 & - \\
\cline { 2 - 8 } & $x_{2}$ & 0.94 & 2.02 & 1.03 & 1.61 & 1.09 & - \\
\hline $\begin{array}{c}\text { Total number } \\
\text { of manufactured products }\end{array}$ & $x_{1}$ & - & 79.3 & 157.1 & 237.7 & 315.26 & 396.4 \\
\cline { 2 - 8 } & $x_{2}$ & - & 298.7 & 596.8 & 894.4 & 1194.8 & 1493.7 \\
\hline
\end{tabular}

Table 2. Obtained control results for $\alpha=100$

\begin{tabular}{|c|c|c|c|c|c|c|c|}
\hline \multirow{2}{*}{ Means of production category } & \multicolumn{7}{|c|}{ Production control moments } \\
\cline { 2 - 9 } & & $n_{0}$ & $n_{1}$ & $n_{2}$ & $n_{3}$ & $n_{4}$ & $n_{5}$ \\
\hline \multirow{2}{*}{$\begin{array}{c}\text { Number of produced good } \\
\text { quality products }\end{array}$} & $x_{1}$ & 0 & 79.2 & 159.2 & 239.2 & 318.6 & 397.7 \\
\cline { 2 - 9 } & $x_{2}$ & 0 & 299.0 & 598.4 & 895.6 & 1197.2 & 1498.8 \\
\hline $\begin{array}{c}\text { Demand for the means } \\
\text { of production for the next } \\
\text { period }\end{array}$ & $m$ & 754.0 & 755.0 & 755.6 & 759.1 & 762.4 & 0 \\
\cline { 2 - 8 } & $l$ & 2408.0 & 2410.4 & 2412.6 & 2425.1 & 2432.2 & 0 \\
\hline $\begin{array}{c}\text { Number of forecasted } \\
\text { faulty products }\end{array}$ & $x_{1}$ & 0.82 & 0.13 & 0.29 & 0.95 & 2.28 & 0 \\
\cline { 2 - 8 } & $x_{2}$ & 0.98 & 0.85 & 3.36 & 0.57 & 1.20 & 0 \\
\hline $\begin{array}{c}\text { Total number } \\
\text { of manufactured products }\end{array}$ & $x_{1}$ & - & 80.0 & 159.3 & 239.5 & 319.5 & 400.00 \\
\cline { 2 - 8 } & $x_{2}$ & - & 300.0 & 599.2 & 899.0 & 1197.8 & 1500.0 \\
\hline
\end{tabular}


Table 3. Obtained control results for $\alpha=5000$

\begin{tabular}{|c|c|c|c|c|c|c|c|}
\hline \multirow{2}{*}{ Means of production category } & \multicolumn{7}{|c|}{ Production control moments } \\
\cline { 2 - 8 } & & $n_{0}$ & $n_{1}$ & $n_{2}$ & $n_{3}$ & $n_{4}$ & $n_{5}$ \\
\hline \multirow{2}{*}{$\begin{array}{c}\text { Number of produced good } \\
\text { quality products }\end{array}$} & $x_{1}$ & - & 78.8 & 158.9 & 238.7 & 313.8 & 399.8 \\
\cline { 2 - 8 } & $x_{2}$ & - & 297.9 & 597.2 & 896.0 & 1197.6 & 1499.8 \\
\hline $\begin{array}{c}\text { Demand for the means } \\
\text { of production } \\
\text { for the next period }\end{array}$ & $m$ & 754.0 & 755.7 & 756.6 & 759.3 & 772.8 & - \\
\cline { 2 - 8 } & $l$ & 2408.0 & 2412.8 & 2415.8 & 2424.3 & 2444.3 & - \\
\hline $\begin{array}{c}\text { Number of forecasted } \\
\text { faulty products }\end{array}$ & $x_{1}$ & 1.22 & 0.15 & 0.58 & 0.40 & 0.19 & - \\
\cline { 2 - 8 } & $x_{2}$ & 2.13 & 1.19 & 2.12 & 5.54 & 0.17 & - \\
\hline $\begin{array}{c}\text { Total number } \\
\text { of manufactured products }\end{array}$ & $x_{1}$ & - & 80.0 & 159.0 & 239.3 & 314.2 & 400.00 \\
\cline { 2 - 8 } & $x_{2}$ & - & 300.0 & 598.4 & 898.1 & 1203.1 & 1500.0 \\
\hline
\end{tabular}

\section{Conclusion}

In an increasingly time-based competitive environment, Just-in-Time manufacturing plays an important role. It forces companies to realize production processes in more efficient and cost-effective way. This casts new light on the problem of production planning and control. In consequence, it is necessary to try to develop new, more efficient methods which support operation activities in this area. The problem focuses especially on the task of difficulty with predicting the number of failure parts that arise during the production process. They disturbs the process and make the requirements for materials unpredictable.

In this study, a mathematical model of production control for a fixed horizon is proposed. The objective function is the total cost which is the sum of production costs and costs associated with failure to perform the contract. The control of production is realized in defined moment during the time horizon determined for example by the customer. In each of the moment we get the quantity of means of production needed in the foreseeable accounting period of time. The number of produced part in each period is determined taking into account stochastic independence of failure products manufacturing. Provided experiments proved that presented model is sensitive to costs of manufacturing and possible penalties connected with failure to perform the contract. While the unit penalty is growing up, the number of produced parts is approaching to the expect value.

The model described above can be easily implemented and used as a tool for control the production processes. The developed solution is first of all dedicated for the operation and internal supply chain managers. 


\section{References}

[1] M. RELICH: Fuzzy project scheduling using constraint programming. Applied Computer Science, 9(2013)1, 3-16.

[2] S.I. SOTOGLU, I.E. SAHIN: Design of a just-in-time periodic material supply system for the assembly lines and an application in electronics industry. International Journal of Advanced Manufacturing Technology, 65(2013), 319-332.

[3] ŚWIĆ A., GOLA A.: Economic analysis of casing parts production in a flexible manufacturing system. Actual Problems of Economics, 141(2013)3, 526-533.

[4] A. GOLA, A. ŚWIĆ: Computer-aided machine tool selection for focused flexibility manufacturing systems using economical criteria. Actual Problems of Economics, 124(2011)10, 383-389.

[5] U.S. KARMAKAR, P.J. LEDERER, J.L. ZIMMERMAN: Choosing manufacturing production control and cost accounting systems, R.S. KAPLAN (ed.), Measures for Manufacturing Excellence, 1990, 353-396.

[6] D. GA¿SKA, A. ŚWIĆ: Practical implementation of computerized production management information system in a production company. Applied Computer Science, 6(2010)1, 75-90.

[7] J.C. FRANSOO: A typology of production control situations in process industries. International Journal of Operations \& Production Management, 14(1994)12, 4757.

[8] H. CHEN, P. YANG, D. YAO, X. CHAO: Optimal control of a simple assembly system. Operations Research Letters, 14(1993)4, 199-205.

[9] S. BENJAAFAR, M. ElHAFSI: Production and inventory control of a single product assemble-to-order system with multiple customer classes. Management Science, 52(2006)12, 1896-1912.

[10] S. BENJAAFAR, M. ElHAFSI, C.Y. YEE, W. ZHOU: Optimal control of assembly systems with multiple stages and multiple demand classes. Operations Research, 59(2011) 2, 522-529.

[11] W.P. MILLHISER, N.B. APOSTOLOS: Optimal admission control in series production systems with blocking. IIE Transactions, 45(2013)10, 1035-1047.

[12] S.B. GERSHWIN: Design and operation of manufacturing systems: The controlpoint policy. IEE Transactions, 32(2000), 891-906.

[13] H.J. KUSHNER: Control and optimal control of assemble to order manufacturing systems under heavy traffic. Stochastics and Stochastic Reports, 6(1999)3\&4, 233272.

[14] E.L. PLAMBECK, A.R. WARD: Optimal control of a high-volume assemble-toorder system with maximum leadtime quotations and expediting. Queuing Systems, 60(2008)1-2, 1-69.

[15] O. CERYAN, I. DUENYAS, Y. KOREN: Optimal Control of an Assembly System with Demand for the End-Product and Intermediate Components. IEE Transactions, 44(2012)5, 386-403.

[16] G.L. LIAO: Optimal economic production quantity policy for randomly failing process with minimal repair, backorder and preventive maintenance. International Journal of System Science, 44(2013)9, 1602-1612. 
[17] M. SARKAR, B. SARKAR: An economic manufacturing quantity model with probabilistic deterioration in a production system. Economic Modeling, 31(2013), 245-252.

[18] D. GHELASE, L. DASCHIEVICI, V. MARINESCU, A. EPUREANU: Method for control of the make-to-order manufacturing system on the base of earning power assessment. International Journal of Advanced Manufacturing Technology, 65(2013)9-12, 1439-1458.

[19] E. KOZŁOWSKI: Identification of linear system in random time. International Journal of Computer and Information Technology, 1(2011), 103-108.

[20] E. KOZŁOWSKI: The linear quadratic stochastic optimal control problem with random horizon at finite number of events independent of state system. System Science, 36(2010)3, 5-11.

[21] R. BELLMAN: Adaptive control processes. Princeton 1961.

[22] W.H. FLEMING, R. RISHEL: Deterministic and stochastic optimal control, Springer-Verlag, Berlin 1975.

Received in October 2013 